\title{
THE ESTIMATION OF CACAO SHELL.
}

By ARTHUR W. KNAPP, B.So., F.I.C., and BASIL G. MoLELLAN, F.I.O.

(Read at the Meeting, November 6, 1918.)

THE estimation of cacao shell has received the attention of many able chemists, but it is doubtful if all the factors influencing the different methods or the limitations of their accuracy have been taken into account. In view of the exceptional facilitiea at our disposal for the examination of authentic samples, we think that some record of our joint experience may be of use.

Variation in Quantity and Character of Sheli on Beans.

(a) Variation due to Botanic Variety.-The different botanic varieties have distinctly different properties, and this is one of the causes of the varying characters of the shell from cacao of different geographical origin. In many places the different varieties may be found growing on the same plantation. Thus, taking beans from cacao-trees growing side by side in Trinidad, and preparing the caco in exactly the same way (without claying), we obtained 13.3 per cent. of shell in Trinidad criollo, and $15 \cdot 1$ per cent. of shell on the Trinidad calabacillo (a more hardy variety with a smaller bean).

(b) Variation due to Condition and Preparation of the Bean.-Not only does the original caca vary, but the character of the shell varies with the ripeness of the cacao when gathered. Cacao from the same plantation, and therefore, presumably, a mirture of the same botanio varieties, was gathered in different stages of ripeness.

\begin{tabular}{llllll|c}
\hline \multicolumn{3}{c}{ Raw Unclayed Trinidad Oacso. } & & Shell per Oent. \\
\hline Unripe & $\ldots$ & $\ldots$ & $\ldots$ & $\ldots$ & $\ldots$ & $14 \cdot 3$ \\
Ripe $\ldots$ & $\ldots$ & $\ldots$ & $\ldots$ & $\ldots$ & $\ldots$ & $13 \cdot 5$ \\
Overripe & $\ldots$ & $\ldots$ & $\ldots$ & $\ldots$ & $\ldots$ & $12 \cdot 3$ \\
Germinated & $\ldots$ & $\ldots$ & $\ldots$ & $\ldots$ & $5 \cdot 0$ \\
\hline Unfermented & $\ldots$ & $\ldots$ & $\ldots$ & $\ldots$ & $18 \cdot 5$ \\
Sweepings (pascilla) & $\ldots$ & $\ldots$ & $\ldots$ & $32 \cdot 9$ \\
\hline
\end{tabular}

The shell on commercial cacao consists of true shell plus pulp and dirt. Every country has a different method of preparing the cacko for the market, and this affects 
the character of the shell. Thus, in those countries where the cacao is not fermented or washed to remove the fruity pulp with which the bean is surrounded, some of the pulp remains dried on the shell. Hence the high figure, 18.5 per cent. for unfermented caca given above. More or less care is taken in separating the broken beans, and about 5 per cent. of sweepings are produced, containing 33 per cent. of shell. These sweepings sometimes get mixed with the whole beans.

Washing.--In some countries the shell is washed quite clean, the pulp being entirely removed. Thus washed, Ceylon gives only 8 per cent. of shell, and whilst the shell of normal Accra cacao amounts to $12 \cdot 2$ per cent., that from washed Accra averages only 9.5 per cent. This gives us some idea how much of the so-called shell is true shell, and how much is dried pulp and dirt.

Claying.-As shell is sometimes used as human food, the presence of clay is of interest. In the preparation of cacao the juicy bean has to be dried, and whilst it is drying its outside is sticky and is liable to pick up any dirt with which it comes in contact. However, some of the finest cacao-e.g., certain varieties from Trinidad and Venezuela-are deliberately coated with a thin layer of clay or earth.

In our opinion, the ash of clean shell does not exceed 8 per cent. (we find that the ash of Ceylon cacao shell is only 5 per cent.) ; the ash of those which are practically free from earth-Arriba 6 per cent., Grenada, Jamaica, and Samoa 7 per cent., Accra 8 per cent. ; the ash of those which are slightly earthed, Machala and Bahia 9 per cent.; whilst Trinidad gives 15 per cent., Columbian 17 per cent., and Carupano 24 per cent. From these figures it is evident that Trinidad cacao shell contains 7 per cent. of clay, whilst Columbian contains 9 per cent. and Carupano 16 per cent. of red earth. We think one would hesitate to recommend these last three shells for human food. The amount of clay is liable to considerable variation. Thus, analyses of ten lots of Trinidad cacao gave-

$\begin{array}{llllll}\text { Shell } & \ldots & \ldots & \ldots & 13.5 \text { to } 17.4 \text { per cent. } \\ \text { Ash in shell } & \ldots & \ldots & \ldots & 10.4,23.4 & , \\ \text { Clay on bean } & \ldots & \ldots & \ldots & 0.3, " 2.7 & , \\ \text { Clay on shell } & \ldots & \ldots & \ldots & 2.4,15.4 & \end{array}$

(c) Variation with Country of Origin.-We give some figures below illustrating this, but it will be recognised that cacao from one country, or even. from one plantation, is liable to vary considerably, so that to give reliable average figures for any particular producing area would require many analyses. The average of six samples taken monthly in 1918 gave the following shell percentages :

$$
\begin{array}{lllllr}
\text { Ceylon } \ldots & \ldots & \ldots & \ldots & \ldots & 7 \cdot 9 \\
\text { Para } \ldots & \ldots & \ldots & \ldots & \ldots & 10 \cdot 4 \\
\text { Bahia } \ldots & \ldots & \ldots & \ldots & \ldots & 12 \cdot 1 \\
\text { Accra } \ldots & \ldots & \ldots & \ldots & \ldots & 12 \cdot 2 \\
\text { Machala } & \ldots & \ldots & \ldots & \ldots & 12 \cdot 5 \\
\text { Arriba } \ldots & \ldots & \ldots & \ldots & \ldots & 12 \cdot 7 \\
\text { Grenada } & \ldots & \ldots & \ldots & \ldots & 14 \cdot 5 \\
\text { Trinidad } & \ldots & \ldots & \ldots & \ldots & 15 \cdot 8
\end{array}
$$

These figures are for raw shell ; they were obtained by separating the shell from the beans by hand. Roasting reduces the apparent percentage of shell by 1 to 3 per cent. 
We now propose to deal critically with the various processes which have been suggested for the estimation of shell.

\section{Crude Fibre.}

(a) Official Method of the Association of Official Agricultural Chemists, U.S.A., also called Weender's and also Henneberg's Process. (See Allen's "Commercial

Organic Analysis," 1909, vol. i., p. 70.)

Results obtained by this method :

Crude Fibre: Phrcentage on Fat-free Material.

\begin{tabular}{|c|c|c|}
\hline & Roasted Nib. & Roasted Shell. \\
\hline 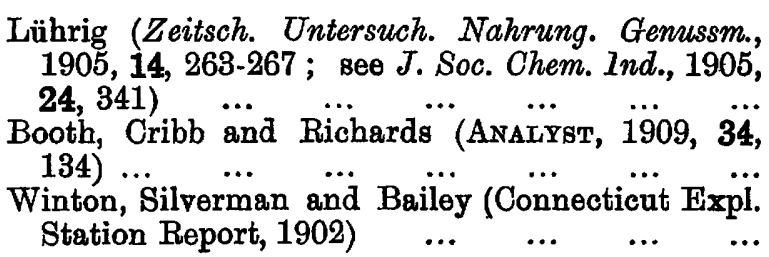 & $\begin{array}{c}- \\
4 \cdot 7 \text { to } 6 \cdot 2 \\
4 \cdot 7,6 \cdot 6\end{array}$ & $\begin{array}{l}11 \cdot 1 \text { to } 19.8 \\
13 \cdot 2,16.3 \\
13.7,20.7\end{array}$ \\
\hline
\end{tabular}

Effect of Size of Particles.-The above process applied to roasted nib in various degrees of fineness, all of which were comparable with the size of the ordinary cocoa powder of commerce, gave the following results: Very finely ground, 5.9 to 6.5 per cent. ; finely ground, 7.3 to 8.5 per cent. ; slightly coarser, 9.3 to 11.6 per cent. This has an important bearing on the use of the process, and shows the necessity for obtaining the samples in the same state of division. The variation is probably due to the remarkable difficulty which is experienced in extracting the fat from coarse cacao particles, the fat protecting the particles from the action of the weak acid and alkali. On the other hand, in the case of shell, we found, to our surprise, that the size had very little influence on the fibre figure. Taking a mixed shell, we ground it to various degrees of fineness and obtained the following results :

\begin{tabular}{|c|c|c|}
\hline $\begin{array}{l}\text { Size of Particles of Shell } \\
\text { (Inches). }\end{array}$ & $\begin{array}{c}\text { Ether }(0.720) \text { Extract } \\
\text { (per Cent.). }\end{array}$ & $\begin{array}{l}\text { Fibre on Fat-Free } \\
\text { (per Cent.). }\end{array}$ \\
\hline $\begin{array}{l}\text { Whole shell. } \\
0.083 \text { to } 0.125 \\
0.033 \text { " } 0.055 \\
0.022 " 0.033 \\
0.011 " 0.022 \\
0.006,0.011 \\
0.004,0.006 \\
\text { Less than } 0.004\end{array}$ & $\begin{array}{l}2 \cdot 46 \\
2 \cdot 64 \\
2 \cdot 82 \\
2 \cdot 83 \\
3 \cdot 41 \\
3 \cdot 96 \\
4 \cdot 62 \\
6 \cdot 85\end{array}$ & $\begin{array}{l}40 \cdot 3 \\
15 \cdot 1 \\
14 \cdot 1 \\
14 \cdot 1 \\
14 \cdot 0 \\
14 \cdot 5 \\
14 \cdot 0 \\
14 \cdot 2\end{array}$ \\
\hline
\end{tabular}


(The rise in the ether extract with increasing fineness is of considerable interest, suggesting that unless the cells are actually broken the extraction is incomplete, and the butyro-refractometer figure for the extracts at $40^{\circ} \mathrm{C}$. rose with fineness from $57 \cdot 0$ to 60.0 , or the refractive index from 1.4639 to 1.4659 . It is evident that the extract contained a fair percentage of resins with the cacao butter.)

The method under review is a general method for grains, seeds, etc., and as it promised to be of some value for cocor products, a modification was adopted to meet the peculiarities of this particular material. As seven experimenters all followed this process, we give the details in full. Possibly the most important modification is the use of a filter-paper in place of linen for filtration. This probably accounts for the results being higher than those on the official process.

Per Centy. of Crude fibre on Dry Fat-Free Material.

\begin{tabular}{|c|c|c|c|c|c|c|c|}
\hline & $\begin{array}{c}\text { Fat } \\
\text { (Per } \\
\text { Cent.). }\end{array}$ & $\begin{array}{c}\text { Fry's } \\
\text { Labora- } \\
\text { tory. }\end{array}$ & $\begin{array}{l}\text { Rowntree's } \\
\text { Laboratory. }\end{array}$ & Mean. & $\begin{array}{l}\text { Cadbury's } \\
\text { Laboratory. }\end{array}$ & Mean. & 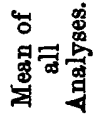 \\
\hline Pure cocoa & $25 \cdot 5$ & (a) 5.89 & $\begin{array}{l}\text { (b) } 5 \cdot 4,5 \cdot 6 \\
\text { (c) } 6 \cdot 0,6 \cdot 2 \\
\text { (d) } 6 \cdot 8,6 \cdot 8\end{array}$ & $\begin{array}{l}5 \cdot 50 \\
6 \cdot 09 \\
6 \cdot 78\end{array}$ & $\begin{array}{c}\text { (e) } 5 \cdot 6,5 \cdot 7,4 \cdot 6,4 \cdot 9 \\
5 \cdot 4,5 \cdot 6 \\
(f) 5 \cdot 7,5 \cdot 9,5 \cdot 9,6 \cdot 0 \\
(g) 5 \cdot 3,5 \cdot 6,5 \cdot 8,5 \cdot 6 \\
5 \cdot 2,5 \cdot 6\end{array}$ & $\begin{array}{l}5 \cdot 29 \\
5 \cdot 87 \\
5 \cdot 60\end{array}$ & $5 \cdot 86$ \\
\hline $\begin{array}{l}10 \text { per cent. } \\
\text { shell }\end{array}$ & $23 \cdot 6$ & (a) $7 \cdot 50$ & 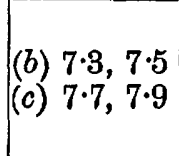 & $\begin{array}{l}7 \cdot 39 \\
7 \cdot 83\end{array}$ & $\begin{array}{c}\text { (e) } 6 \cdot 9,6 \cdot 9 \\
(f) 7 \cdot 4,7 \cdot 7,8 \cdot 0 \\
(g) 6 \cdot 4,7 \cdot 0,6 \cdot 9,7 \cdot 6 \\
7 \cdot 2,7 \cdot 3,7 \cdot 2\end{array}$ & $\begin{array}{l}6 \cdot 90 \\
7 \cdot 70 \\
7 \cdot 09\end{array}$ & $7 \cdot 44$ \\
\hline $\begin{array}{l}20 \text { per cent. } \\
\text { shell }\end{array}$ & $21 \cdot 5$ & (a) 8.80 & $\begin{array}{l}\text { (b) } 9 \cdot 1,9 \cdot 1 \\
\text { (c) } 8 \cdot 8,8 \cdot 8\end{array}$ & $\begin{array}{l}9 \cdot 06 \\
8 \cdot 82\end{array}$ & $\begin{array}{l}\text { (e) } 7 \cdot 9,8 \cdot 3 \\
\text { (g) } 8 \cdot 3,8 \cdot 5,8 \cdot 0,8 \cdot 1 \text {, } \\
8 \cdot 2\end{array}$ & $\begin{array}{l}8 \cdot 09 \\
8 \cdot 21\end{array}$ & $8 \cdot 63$ \\
\hline $\begin{array}{l}50 \text { per cent. } \\
\text { shell }\end{array}$ & $15 \cdot 1$ & (a) $12 \cdot 76$ & 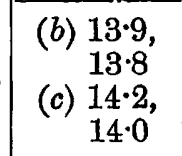 & $\begin{array}{l}13 \cdot 81 \\
14 \cdot 08\end{array}$ & $\begin{array}{l}\text { (e) } 12 \cdot 6,12 \cdot 8 \\
\text { (g) } 12 \cdot 5,12 \cdot 9,12 \cdot 8 \text {, } \\
12 \cdot 8,12 \cdot 8\end{array}$ & $\begin{array}{l}12 \cdot 68 \\
12 \cdot 78\end{array}$ & $13 \cdot 14$ \\
\hline $\begin{array}{c}100 \text { per cent. } \\
\text { shell }\end{array}$ & $5 \cdot 1$ & (a) $19 \cdot 20$ & 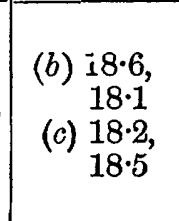 & $\begin{array}{l}18 \cdot 35 \\
18 \cdot 33\end{array}$ & $\begin{array}{c}\text { (e) } 16 \cdot 5,18 \cdot 3,17 \cdot 3 \\
17 \cdot 1 \\
\text { (f) } 19 \cdot 0,18 \cdot 8,19 \cdot 9 \\
\text { (g) } 16 \cdot 6,17 \cdot 0,16 \cdot 8 \\
16 \cdot 5,16 \cdot 5,17 \cdot 3, \\
18 \cdot 8\end{array}$ & $\begin{array}{l}17 \cdot 29 \\
19 \cdot 20 \\
17 \cdot 06\end{array}$ & $18 \cdot 46$ \\
\hline
\end{tabular}

Process adopted for Fibre Estimation.-Extract a quantity of the substance so as to have at least 2 grms. of dry fat-free material for the estimation of the crude fibre. The fat may be removed by any approved solvent, such as ether, petroleum ether, etc. Transfer $2 \mathrm{grms}$. of dry fat-free matter to a 500 c.c. 
flask, and add 200 c.c. of sulphuric acid of strength 1.25 per cent. by weight. Connect the flask with an inverted condenser, using a rubber stopper. Bring to the boil, and maintain the boiling for thirty minutes. Filter through ordinary filter-paper, wash with boiling water until the washings are no longer acid. Rinse the substance back into the flask with not more than 200 c.c. of water (use hot water if preferred), and add 2.5 grms. of sodium hydroxide (stick, flake, or other form, provided it is pure and approximately 98 per cent. strength). Boil at once, and continue the boiling for exactly thirty minutes in the same manner as directed above for the treatment with acid. Filter at once rapidly, either $(a)$ through double tared or counterpoised filter papers, wash with boiling water until the washings are neutral, dry in steam-oven to constant weight, weigh, incinerate completely, and weigh again ; or $(b)$ through a single filter-paper. Wash with boiling water until the washings are neutral, and then wash the fibre into a tared dish and evaporate to constant weight. The fibre is then ignited in the dish and the ash determined. The loss in weight in either method is considered to be crude fibre.

Errors due to the Process.-Wo decided to determine how far analysts following the prescribed process would agree. Hand-picked, shell-free cocoa and cocoa-free shell were prepared on a large scale, and these were mixed in certain proportions, and examined by seven analysts who were unaware of their composition. The results are expressed to only one place of decimal, but the averages are calculated on the actual figures obtained. In these tests we had the advantage of the co-operation of Dr. Bywaters (of Messrs. Fry and Sons).

An examination of these figures shows the fibre estimation-(1) does not give such good duplicates as might be expected; (2) is greatly influenced by the personal equation. If an analyst only makes one estimation, he may get an experimental error of 6 to 8 per cent. on the shell percentage. However, we will assume that he takes the mean of at least two estimations, and that he accepts 5.8 as the fibre figure for cocoa and 18.5 as the fibre figure for shell, then from the above table we obtain the following results :

Phr Cent. of Shelt in Cocoa.

\begin{tabular}{|c|c|c|c|c|c|c|c|}
\hline Present. & \multicolumn{6}{|c|}{ Found by Analysts- } & Mean. \\
\hline $\begin{array}{l}10 \\
20 \\
50\end{array}$ & $\begin{array}{c}(a) \\
10 \cdot 2 \\
18.5 \\
46.5\end{array}$ & $\begin{array}{c}\stackrel{(b)}{9} 6 \\
20 \cdot 1 \\
53 \cdot 6\end{array}$ & $\begin{array}{c}(c) \\
12 \cdot 2 \\
18 \cdot 7 \\
55 \cdot 4\end{array}$ & $\begin{array}{c}(e) \\
6 \cdot 6 \\
14 \cdot 2 \\
46 \cdot 0\end{array}$ & $\begin{array}{c}(f) \\
11 \cdot 4 \\
- \\
-\end{array}$ & $\begin{array}{r}(g) \\
7 \cdot 8 \\
14.9 \\
46.7\end{array}$ & $\begin{array}{r}9 \cdot 9 \\
17 \cdot 5 \\
49 \cdot 1\end{array}$ \\
\hline
\end{tabular}

Several analysts found small quantities up to $5 \cdot 7$ per cent. of shell in the pure cocoa, and, as will be seen from the table, found from 6.6 to $12 \cdot 2$ per cent. in a cocoa containing 10 per cent. It would appear that even when the process is carefully defined it is necessary for each analyst to determine his own figures for pure cocoa and pure shell from the average of a large number of results. 
We have made a few experiments with a view to increasing the agreement between different analysts.

(1) Filtering.-We prefer filter-paper to linen, because of the extreme fineness of the cocoa particles, and also because of the difficulty of defining the exact mesh for linen. We have used $12.5 \mathrm{~cm}$. Swedish and Whatman No. 1, and find they give very similar results. The objection to filter-paper is the difficulty of removing the material without bringing away some of the filter-paper itself. It may be that copper gauze with 100 meshes to the linear inch (Fairley and Burrell, J. Soc. Chem. Ind., 1918, 37, 155T), or an even closer mesh, would prove the most satisfactory filtering medium.

(2) Strength of Acid and Alkali.-We find that within narrow limits the variation in the strength of sulphuric acid and sodium hydroxide used is of little importance.

(3) The Time of Boiling.-The time of boiling should be rigidly adhered to, especially in the case of the alkaline treatment. The rate of boiling might with advantage be standardised, possibly by the use of an oil-bath at $120^{\circ} \mathrm{C}$.

(4) It will be found more convenient to wash off the acid residue with 175 c.c. of hot water, and add 25 c.c. of 10 per cent. sodium hydroxide, instead of using 2.5 grms. of the solid, as given in the above process.

Differences due to Variation in the Nature of the Shell.-The percentage of fibre in the shell is naturally affected by the ripeness of the cacao when gathered and the amount of fermentation it undergoes. Cacao frow the same plantation in Trinidad was carefully collected in bulk in an unripe, ripe, over-ripe, and germinated condition, and fermented separately. Some ripe cacao was dried without fermentation. The mean of two estimations for fibre gave the following figures:

\begin{tabular}{|c|c|c|c|c|c|}
\hline & & & & & Per Cent. \\
\hline Unripe ... & & & & $\cdots$ & $14 \cdot 3$ \\
\hline $\operatorname{Ripe} \quad \ldots$ & $\ldots$ & ... & $\ldots$ & ... & $17 \cdot 0$ \\
\hline Over-ripe & $\ldots$ & $\ldots$ & $\ldots$ & $\ldots$ & $16 \cdot 0$ \\
\hline Germinated & $\ldots$ & $\ldots$ & $\ldots$ & $\ldots$ & $21 \cdot 2$ \\
\hline Unfermented & $\ldots$ & $\ldots$ & $\ldots$ & $\ldots$ & $19 \cdot 0$ \\
\hline
\end{tabular}

These figures help one to understand the variations which occur with beans from different countries.

Country of Origin.-The various beans were given a low-temperature roast (the interior of bean probably not exceeding $120^{\circ} \mathrm{C}$. to $130^{\circ} \mathrm{C}$.). The shell was picked off by hand (the germs being excluded), ground, and passed through a sieve (diameter of holes 0.02 inch). It was then extracted for twenty-four hours, and dried in a water-oven. Two analysts, $(a)$ and $(b)$, determined the fibre by the method described, and each analyst did at least two estimations on each sample. The results are only expressed to one decimal place, as to give more would be indicating that the process is capable of greater accuracy than it is.

The number of factors influencing the percentage of fibre is so great that an examination of the above table reveals no obvious relation between the fibre and the botanic variety of the bean, its fermented condition or other natural property. If we assume as before, for calculation purposes, that shell contains 18.5 per cent. of fibre, then, if we have 20 per cent. of shell in the fat-free material, we shall find 
15.4 per cent. or 24.0 per cent. of shell according as the shell is that of Grenada or Acera beans. It should not be forgotten, however, that as a rule commercial cocoa is a blend of two or more different kinds of bean. Our figures are in general agreement with those of Winton, Silverman, and Bailey, who obtained a minimum of $13 \cdot 7$, a maximum of $20 \cdot 7$, and a mean of $18 \cdot 0$.

Fibre in Roasted Cadao Shell.

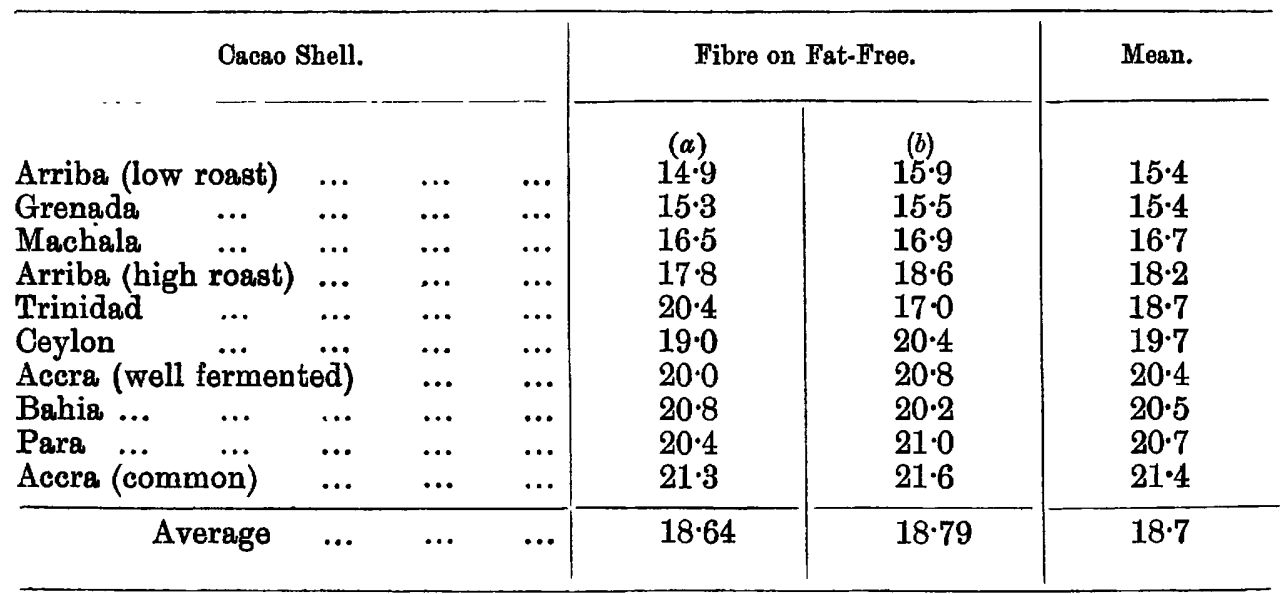

Effect of Roasting.-It is unlikely that the analyst will encounter raw shell in cocoa; however, a small amount of raw shell is separated in cleaning the beans, and this raw shell might conceivably be used in cocon, but the shell on the market is always more or less roasted. The surmise that roasting would increase the percentage of fibre was found to be correct. The figures given are the mean of two or three analyses on the same sample. With Ceylon (criollo) cacao shell we obtain raw 17.5 and roasted 20.4. (Winton, Silverman, and Bailey, working on Caracas beans, found in the shell : fibre per cent. raw, 14.7; under-roasted, 15.4; medium roasted, 16.5 ; over-roasted, 16.6.) With West African (forastero) cacao shell, we obtained raw 18.2, and roasted 20.6. With Arriba cacao shell, low roast 15.4, and high roast 18.2. As the cacao bean is subjected to varying degrees of roasting according to the kind of cocoa or chocolate required, all the analytical figures for shell are liable to variation from this cause.

(b) König's Method (Analyst, 1898, 23, 47; and Zipperer, Die Chocolade-Fabrikation, 280, German Edition, 1913).

In this method 3 grms. of the defatted substance are treated with 200 c.c. of glycerol (1.23 sp. gr.), containing 20 grms. per litre of concentrated sulphuric acid, under the pressure of 3 atmospheres for one hour. It is then filtrated whilst hot through an asbestos filter, and after being washed successively with hot water, alcohol, and ether, it is weighed, then burnt, and the ash weighed. The difference between the two weighings expresses the amount of ash-free crude fibre. 
Criticisms on the Method.-The method has met with considerable adverse criticism (Gury, ANALYRT, 1912, 37, 447), and has been modified by Filsinger (Zeitsch. Analyt. Chem. 1900, 223) and by Matthes and Müller (Zeitsch. Untersuch. Nahrungs. Genussm. 1906, 15, 159; also ANALYST, 1906, 31, 159); but as the figures obtained varied from 5.5 to 9.7 per cent. for nib and from $13 \cdot 1$ to 18.2 for shell, the process has nothing to recommend it as compared with the simpler method previously described.

\section{Nitrogen.}

The Kjeldahl-Gunning process was used for the determination of nitrogen, and the utmost care exercised in obtaining pure nib-free shell and pure shell-free nib, the samples being hand-picked. The shell contained no germs. The nitrogen was determined on two separate samples of shell drawn on different days. In the first sample the nitrogen was determined direct on the shell, in the second sample on the fat-free material. As we were unable to obtain petroleum ether, trichlorethylene was used for extraction; this solvent dissolves out some of the theobromine.

\section{Nitrogen in Roasted Shell.}

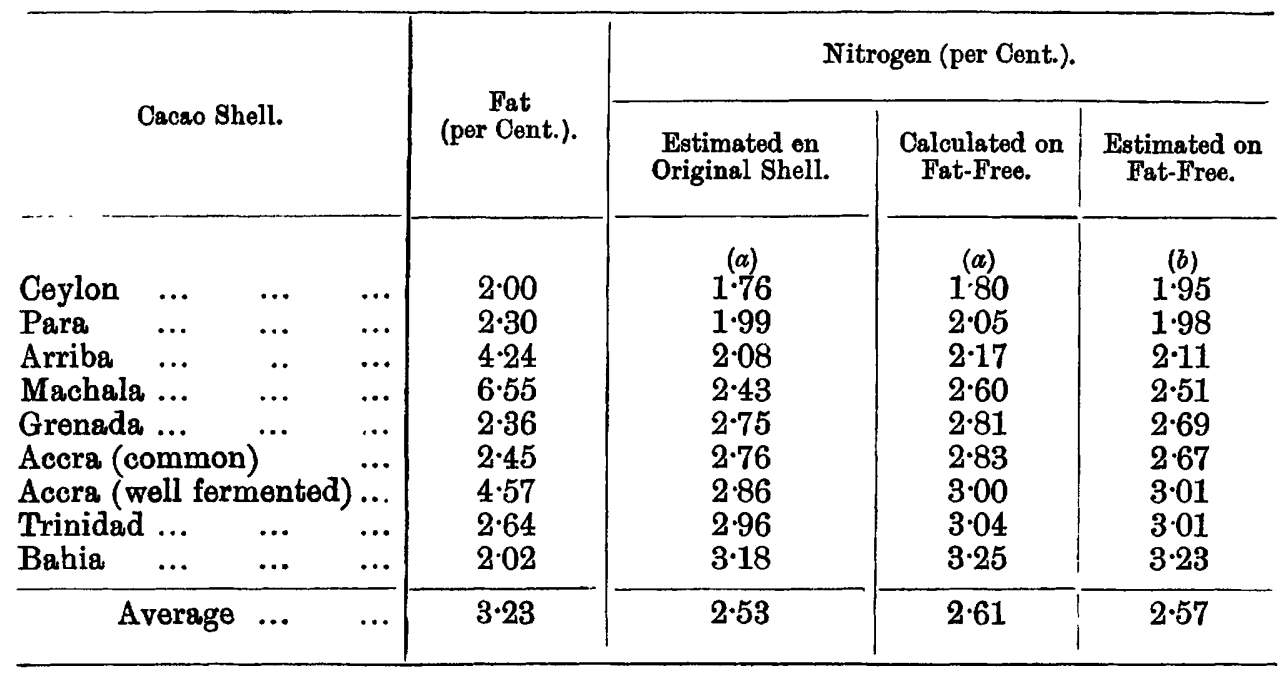

We found that samples taken from different bags of the same consignment often gave good duplicates, and two lots of British West African cacao purchased in Accra and in Liverpool both gave 2.86 per cent. of nitrogen.

We do not suggest that the figures in the table can be taken as giving the average percentage of nitrogen in the shell on beans from a partioular country. To give figures which could be so applied many analyses would have to be made. The figures do, however, give some idea of the range of nitrogen figures for shell. The table below serves the same purpose for nib. The nib came out of the shell in which the nitrogen was determined above (columns marked $a$ ). 
Nitrogen in Roasted Nib.

\begin{tabular}{|c|c|c|c|c|c|c|}
\hline \multirow{2}{*}{\multicolumn{3}{|c|}{ Cacao Nib. }} & \multirow[b]{2}{*}{ Fat (per Cent.) } & \multirow[b]{2}{*}{ Moisture (per Cent.). } & \multicolumn{2}{|c|}{ Nitrogen (per Cent.). } \\
\hline & & & & & $\begin{array}{l}\text { In Original } \\
\text { Nib. }\end{array}$ & $\begin{array}{c}\text { Oalculated on } \\
\text { Dry Fat-Free. }\end{array}$ \\
\hline $\begin{array}{l}\text { Trinidad } \\
\text { Bahia ... } \\
\text { Para ... } \\
\text { Accra (common } \\
\text { Ceylon ... } \\
\text { Accra (well fern } \\
\text { Machala } \\
\text { Grenada } \\
\text { Arriba ... }\end{array}$ & $\begin{array}{l}\ldots \\
\cdots \\
\ldots \\
\text { n) } \\
\cdots \\
\text { ment } \\
\cdots \\
\cdots \\
\cdots\end{array}$ & $\begin{array}{c}\ldots \\
\ldots \\
\ldots \\
\cdots \\
\ldots \\
\ldots \\
\ldots \\
\ldots\end{array}$ & $\begin{array}{l}53 \cdot 94 \\
56 \cdot 14 \\
55 \cdot 03 \\
55 \cdot 47 \\
52 \cdot 08 \\
52 \cdot 76 \\
52 \cdot 38 \\
53 \cdot 96 \\
51 \cdot 73\end{array}$ & $\begin{array}{l}2 \cdot 49 \\
2 \cdot 32 \\
2 \cdot 77 \\
1 \cdot 74 \\
1 \cdot 54 \\
2 \cdot 61 \\
2 \cdot 19 \\
2 \cdot 07 \\
2 \cdot 25\end{array}$ & $\begin{array}{l}2 \cdot 07 \\
2 \cdot 08 \\
2 \cdot 19 \\
2 \cdot 22 \\
2 \cdot 38 \\
2 \cdot 36 \\
2 \cdot 39 \\
2 \cdot 38 \\
2 \cdot 72\end{array}$ & $\begin{array}{l}4 \cdot 75 \\
5 \cdot 01 \\
5 \cdot 19 \\
5 \cdot 19 \\
5 \cdot 13 \\
5 \cdot 29 \\
5 \cdot 26 \\
5 \cdot 41 \\
5 \cdot 91\end{array}$ \\
\hline Average. & ... & $\ldots$ & $53 \cdot 72$ & $2 \cdot 22$ & $2 \cdot 31$ & $5 \cdot 23$ \\
\hline
\end{tabular}

Effect of Roasting.-This is of interest because of the very different amount of roasting which beans undergo for different purposes.

Nitrogen (Per Cent.)

\begin{tabular}{|c|c|c|c|c|}
\hline & \multicolumn{2}{|c|}{ On Original. } & \multicolumn{2}{|c|}{ Calculated on Dry Fat-Free Nib. } \\
\hline & Raw. & Rossted. & Raw. & Roasted. \\
\hline $\begin{array}{llll}\text { Bahia nib } & \ldots & \ldots & \ldots \\
\text { Accra (well-fermented nib) } & \ldots \\
\text { Ceylon nib } & \ldots & \ldots & \ldots\end{array}$ & $\begin{array}{l}1 \cdot 98 \\
2 \cdot 04 \\
2 \cdot 27\end{array}$ & $\begin{array}{l}2 \cdot 08 \\
2 \cdot 36 \\
2 \cdot 38\end{array}$ & $\begin{array}{l}4 \cdot 75 \\
4 \cdot 90 \\
5 \cdot 31\end{array}$ & $\begin{array}{l}5 \cdot 01 \\
5 \cdot 29 \\
5 \cdot 13\end{array}$ \\
\hline $\begin{array}{l}\text { Bahia shell ... } \\
\text { Accra (well-fermentë shell) } \\
\text { Ceylon shell } \ldots\end{array}$ & $\begin{array}{l}2 \cdot 81 \\
2 \cdot 66 \\
1 \cdot 69\end{array}$ & $\begin{array}{l}3 \cdot 18 \\
2 \cdot 86 \\
1 \cdot 76\end{array}$ & - & $\begin{array}{l}3 \cdot 25 \\
3 \cdot 00 \\
1 \cdot 80\end{array}$ \\
\hline
\end{tabular}

The variation due to roasting is appreciable. Winton, Silverman and Bailey found only slight changes, but other experimenters (Zipperer and Ridenour) have found even greater differences. It is reasonable to suppose that in those cases where the cacao is moistened with alkaline carbonates before roasting some nitrogen would be lost.

Criticism.-The value of this figure for the estimation of shell in cocoa is small. However, it has the advantage of being a figure which can be very accurately determined. The variation in the percentage present in fat-free nib is appreciable (we find from 4.75 to 5.91; Winton, Silverman, and Bailey found 4.74 to $5 \cdot 41$ ), whilst that in shell is very great (we find from 1.80 to 3.25 ; Winton, Silverman, and Bailey found 1.87 to 3.41 ). This great variation is not remarkable when we consider 
that we have so great a variety of shell, and that we have theobromine and caffeine as well as a complex mixture of proteins present. In a general way those beans which give a low nitrogen figure for the nib have a high percentage of nitrogen in the shell. In any calculation the germs appear as cocoa, since the dry fat-free germ contains about 6 per cent. of nitrogen. The danger of relying on the percentage of nitrogen to estimate shell may be shown by taking an extreme case. Suppose we imagine Bahia shell mixed with fat-free Arriba nib, then we could have 25 per cent. of shell present before the figure came below the average for nib, or 43 per cent. of shell before the figure came below that for Trinidad nib. This is only by way of illustration. as in practice one has to deal, not with one kind of bean, but with a blend.

\section{Euutriation and Frotation Methods.}

(a) Filsinger and Drawe's Process (Zeitsch. öft. chem., 1899, 5, 27, ibid., 1903, 9, 161 ; ANaLyst, 1903, 28, 216).

Two grms. of the finely powdered fat-free substance are placed in a porcelain dish with 100 c.c. water, and boiled (with continuous agitation) until the powder is thoroughly moistened and the froth disappears. The dish is allowed to stand for five minutes, after which the upper part of the liquid is poured off. It is again filled up with cold water which is allowed to stand, and then poured off. This process is continued until the supernatant liquor is quite clear. The liquid is then given a circular motion and allowed to stand until the solid material is completely settled, after which the liquid is drained off. This is repeated until the supernatant liquor no longer contains any floating particles. The sediment is washed into a Gooch crucible, dried and weighed. The weight obtained is multiplied by the factor 1.43 , obtained by Drawe, and corrects for soluble matter in the shell. The figure so obtained directly represents the quantity of shell present.

Criticisms of the Method.-UIrich (Arch. Pharm., 1911, 249, 537) obtained for roasted nib 0.63 to 0.73 , and for roasted shell $57 \cdot 85$ to $85 \cdot 17$. As a result of his figures he suggests that the factor of 1.43 obtained by Drawe should be increased to 1.72. The fact that one observer has to use a factor of $1 \cdot 43$, while another recommends $1 \cdot 72$, shows that the method is only comparative and subject to personal error.

There can be no doubt that the results obtained with this method are largely dependent upon the sizes of the particles of shell and nib, and also on the manufacturing treatment which the cocoa has received.

(b) Macara's Process (Bolton and Revis, "Fatty Foods," p. 304 ; and Baker and Hulton, ANALYst, 1918, 43, 199).

An outline of the process is given, from which we have worked out the following more detailed procedure :

Fat is completely removed by extraction with petrol from some 10 to 20 grms. of the cocoa, the extraction being continued until the petrol ceases to show even traces of fat when evaporated on a watch-glass. Five grms. of the fat-free material are weighed out and ground up with water in a mortar. The mortar is then filled with water, and after allowing a minute or two to settle, the cocoa, still in suspension, 
is poured into a cylinder. (The dimensions of the cylinders used were 41 to $43 \mathrm{~mm}$. diameter by $280 \mathrm{~mm}$. in height.) The residue still in the mortar is ground up with a further quantity of water, and poured off in the same way into the cylinder until all the material has thus been washed into the cylinder. The cylinder is then filled up with water, thoroughly shaken, and allowed to stand for fifteen minutes. The liquid is syphoned off to within a short distance of the residue lying on the bottom. Ten such elutriations take place, and the liquid is allowed to stand after each for the following times: 15 minutes; 15 minutes; 10 minutes; 7 minutes; and then 6 periods of 5 minutes each. By this time practically no matter should remain in suspension. The residues are then washed on to tared filter papers, dried and weighed, and the ash of the residues deducted from the weights so obtained. It has been found that it is quite convenient to do six samples at a time, and that the time occupied in filling up and shaking the cylinders is practically equal to the time occupied in siphoning off the liquor. By this process we obtained the following results, showing variation with kinds of cacao:

Regidue obtained from 100 Grms. of Fat-Free.

\begin{tabular}{|c|c|c|c|c|c|c|}
\hline \multicolumn{5}{|c|}{ Cacao. } & \multirow{2}{*}{$\begin{array}{c}\text { Roasted Nib. } \\
0 \cdot 28 \\
0 \cdot 40 \\
0 \cdot 90 \\
1 \cdot 40 \\
0 \cdot 40 \\
0 \cdot 40 \\
0 \cdot 10\end{array}$} & \multirow{2}{*}{$\begin{array}{c}\text { Roasted Shell. } \\
19 \cdot 4 \\
20 \cdot 4 \\
23 \cdot 9 \\
24 \cdot 7 \\
26 \cdot 9 \\
29 \cdot 6 \\
30 \cdot 7\end{array}$} \\
\hline $\begin{array}{l}\text { Bahia } \ldots \\
\text { Trinidad } \\
\text { Grenada .... } \\
\text { Java } \quad . . \\
\text { Ocumare } \\
\text { Acora } \quad . . \\
\text { Arriba } \quad \ldots\end{array}$ & $\begin{array}{l}\ldots \\
\cdots \\
\cdots \\
\cdots \\
\cdots \\
\cdots\end{array}$ & $\begin{array}{l}\cdots \\
\cdots \\
\cdots \\
\cdots \\
\cdots \\
\cdots \\
\cdots\end{array}$ & $\begin{array}{l}\cdots \\
\cdots \\
\cdots \\
\cdots \\
\cdots \\
\cdots\end{array}$ & $\begin{array}{l}\ldots \\
\ldots \\
\cdots \\
\cdots \\
\ldots \\
\ldots \\
\ldots\end{array}$ & & \\
\hline Mear & $\ldots$ & $\ldots$ & $\ldots$ & $\ldots$ & 0.28 & $25 \cdot 2$ \\
\hline
\end{tabular}

Criticisms of the Method.-This process, being a modification of the FilsingerDrawe process, is subject to the same criticisms. With cocoas which were known to contain a large percentage of shell and which had been submitted to the "Dutch" process, we have obtained figures for sediment which would classify these as free from shell.

For the experiments below the details of the process more closely resembled those described by Bolton and Revis, in that 10 grms. of defatted material were taken, the periods of standing were $15,15,10,5,5,5,5$, and 5 minutes, and the residue was dried and weighed in a tared platinum dish. Revis and Bolton recommend $10 \mathrm{grms}$. to be defatted and the shell to be estimated on this 10 grms. in which case the Soxhlet thimble would have to be scraped clean. It is obviously better to run a fat estimation at the same time, and take an accurately weighed portion of the fat-free substance. The fat-free residue is ground in a mortar. It is practically impossible to standardise this grinding, which, unfortunately, considerably affects the result. Thus a fat-free cacao mass when ground for five minutes gave 38.7 per cent. residue, 
and when ground for 10 minutes 26.8 residue. We decided to grind the material for fifteen minutes.

In Revis and Bolton's account they state that with shell 90 per cent. of the residue can be distinguished as spiral vessels and solerenchymatous tissue. In practice we find the pure shell powder does not give more than 40 per cent. of such material, the remainder being masses of cells of indefinite structure.

In some experiments performed under our direction by Mr. J. H. Hicklin, M.A., the greatest care was taken to extract the very last trace of fat, the conditions for adding the water to the cylinder were standardised (it was found an advantage to hold the cylinder slightly at an angle, so that the water ran smoothly down and did not form bubbles), and the procedure in siphoning was carefully considered. The siphon was turned up one-tenth the height of the water (i.e., depth occupied by 50 c.c.); it was always lowered gradually, and was lowered until the bend just touched the upper surface of the sediment. The times of "resting" were most rigidly adhered to. In spite, however, of the most elaborate precautions, duplicates did not agree well, and the results for $5,10,15,20,25,30,50$, and 100 per cent. shell when plotted did not lie on a straight line.

$\begin{array}{lllllllllll}\text { Shell per cent. } & \ldots & \ldots & 0 & 5 & 10 & 15 & 20 & 25 & 50 & 100\end{array}$

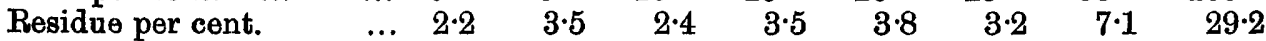

It should be noted that the above experiments were performed on shell which we ourselves ground very fine, but which was not sieved.

Macara (loc. cit.) mentions that the percentage of husk varies according to the degree of fineness to which the cocoa has been ground. The figures below show that the effect is so great as to render the process useless. A cacao shell powder was separated into parts of various sizes.

\begin{tabular}{|c|c|c|}
\hline Size of Shell. & Residue. & Calculated Shell. \\
\hline $\begin{array}{l}0.004 \text { to } 0.009 \text { inch } \\
0.003 \text { \#0.004 " } \\
\text { Less than } 0.009 \text { inch }\end{array}$ & $\begin{array}{c}34.0 \text { per cent. } \\
12.5 \quad ", \\
0.6 \quad "\end{array}$ & $\begin{array}{c}100 \text { per cent. } \\
34 " \\
0 "\end{array}$ \\
\hline
\end{tabular}

As 80 per cent. of the ground shell was less than 0.003 inch in diameter, the significance of its giving a figure lower than that of cocoa is evident.

Thinking possibly that we were not working the process in a satisfactory manner we sent samples containing this shell to a well-known analyst who had faith in the process. In a cocoa containing 13.5 per cent. of shell he found 3 per cent. by the Macara process, and in a cocoa containing 27 per cent. of shell he found 0 per cent., although by other methods he was convinced that shell was present.

(c) Flotation Method-Goske's Process of Flotation in Calcium Chloride Solution (ANaLYst, 1910, 33, 162).

One grm. of the dry fat-free cocon is mixed with a stoppered tube with 20 c.c. of a calcium chloride solution prepared by dissolving $107 \cdot 1$ grms. of caloium chloride in 
100 a.c. of water (this solution should have a sp. gr. of 1.535 at $30^{\circ} \mathrm{C}$.). The stopper of the tube is then removed, the mixture is heated to boiling for two minutes, and while still hot submitted to centrifugal action for six minutes. The liquid portion is now removed, and the almost solid sediment is collected on a weighed filter, washed with hot water until free from chloride, dried at $a, 100^{\circ} \mathrm{C}$, and weighed. From the weight of the sediment of husk obtained the excess quantity of the latter present in the original cocoa is calculated. For this purpose it may be taken that crcao husk itself yields 38.7 per cent. of sediment, and the amount of fat in the cocoa must also be taken into consideration. The figure 38.7 was the highest result obtained on the examination of a number of samples of caca husk, the average result being 24.5 per cent. From the final result obtained a deduction of 6 per cent. is made, this being the quantity of husk yielded by ordinary commercial cocoas.

Criticisms of the Method.-We find the process has many difficulties in practice. It is to be regretted that Goske did not find some suitable solution of sufficient density other than calcium chloride. A solution which sets to a solid mass the moment it is allowed to cool is inconvenient in use. It renders difficult what is essential to success, the obtaining of a homogeneous mixture of cocoa and solution, and further it tends to set during the centrifugal action. In the presence of these difficulties we have failed to obtain satisfactory results with this method on pure cocoa and shell, and the figures on mixtures suggest that either the cocoa floats the shell up, or the shell drags the cocoa down. Filsinger and Bötticher (J. Soc. Chem. Ind., 1910, 29, 1129), and Dubois and Lott (J. Ind. Eng. Chem., 1911, 2, 251), and Schenk, Schmidt, Görbing (Zeitsch. öft. Chem., 1912, 18, 201), have failed to get satisfactory results by this method, which, in our opinion, is unreliable.

Process suggested by Kulusky (Zeitsch. Untersuch. Nahrungs. Genussm., 1912, 21, 654).-This process also depends on the difference in specific gravity of the shell particles and nib particles, and is open to the same criticism as the Goske process. So also is the process suggested by H. Grosse. (See J. Soc. Chem. Ind., 1916, 35, 137).

\section{Pentosan.}

(Tollens and Kröber's Process. J. f. Landw., 1900, 357 ; and Hehner and Skertchly, ANALYst, 1899, 24, 178-183.)

From the quantity of weighed black precipitate of furfurol-phloroglucinol, the quantity of furfurol can be calculated by division by 1.84 , or, more correctly, by means of the figures given in Tollens' table (König, Unters. Landw. u. Gewerbl. wicht Stoffe, 225). From the quantity of furfurol we can obtain the amount of pentosan as follows : Furfurol-0.0104 grm. $\times 1.88=$ pentosan.

Several other methods have been suggested for caloulating this figure, and are as follows :

Calculation Formula.-Let $a=$ weight of furfurol-phloroglucide, $p=$ weight of pentosan required.

(a) Deklker. $-p=\left[\left(\frac{a}{1} \times \frac{1}{1.84}\right)-0.0104 \mathrm{grm}.\right] \times 1.88$. 
(b) Tollens (J. Soc. Chem. Ind., 1907, 26, 987). $-p=(a+0.0052) \times 0.8824$.

(c) Kröber (Allen, "Commercial Organic Analysis," vol. i., p. 403).-(For weights of precipitate from 0.03 to $0.3 \mathrm{grm}$.) $p=(a+0.0052) \times 0.8866$.

(d) From weight of phloroglucide obtain pentosan from Wiley tables per cent.

(e) Formula Adopted. $-p=(a+0.0052) \times 0.89$.

Results obtained by this method:

Pentosan: Percentagh on the Fat-Frem Material.

\begin{tabular}{|c|c|c|c|c|}
\hline & $\begin{array}{l}\text { Rossted } \\
\text { Nib. }\end{array}$ & $\begin{array}{l}\text { Raw } \\
\text { Nib. }\end{array}$ & $\begin{array}{l}\text { Roasted } \\
\text { Shell. }\end{array}$ & $\begin{array}{l}\text { Raw } \\
\text { Shell. }\end{array}$ \\
\hline $\begin{array}{c}\text { Warnier (Zeitsch. Untersuch. Nahr. } \\
\text { ungs. Genussm., 1899, 8, 892) }\end{array}$ & - & $5 \cdot 0$ & - & - \\
\hline Hehner and Skertchley (ANALYST, & & & - & - \\
\hline $\begin{array}{l}\text { 1899, 24, 178-183) .. } \\
\text { Lührig and Segin (Zeitsch. Untersuch. }\end{array}$ & - & $2 \cdot 7$ & - & 8.9 \\
\hline Nahrungs. Genussm., 1906, 15, 162) & - & $2 \cdot 5$ to 4.6 & - & $7 \cdot 6$ to $11 \cdot 2$ \\
\hline $\begin{array}{l}\text { Prochnow ("Dissertation Braunsch. } \\
\text { weig," 1908) } \\
\text { R. Adan (Seventh Internat. Congress }\end{array}$ & $3 \cdot 9$ to $4 \cdot 6$ & $3 \cdot 8,4 \cdot 8$ & $7 \cdot 9$ to $9 \cdot 9$ & - \\
\hline $\begin{array}{l}\text { App. Chem., 1909, Section VIIIIc, } \\
\text { 194) } \ldots\end{array}$ & $2 \cdot 3,3 \cdot 6$ & $2 \cdot 7,3.8$ & - & $7 \cdot 6,10 \cdot 5$ \\
\hline 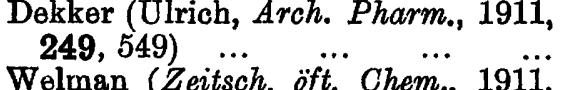 & - & $4.3,4.8$ & $9 \cdot 0$ to $9 \cdot 6$ & $8 \cdot 2$ to $9 \cdot 6$ \\
\hline $\begin{array}{l}17,500) \\
\text { Ulrich (Arch. } \dddot{P} h \text { arm., } 1911, \dddot{249}, 551)\end{array}$ & 3.9 to 4.3 & 3.9 to 4.3 & $8.0 \overline{\operatorname{ta}} 0.7$ & $\begin{array}{l}7 \cdot 5,7 \cdot 5 \\
8 \cdot 2,9 \cdot 8\end{array}$ \\
\hline Uiricn (Arch. Pharm., 1911, 249, & & & 026097 & ס \\
\hline
\end{tabular}

Criticisms of the Method.-The paper by Adan (loc. cit.) created much interest in this process, but it has not stood the test of time. The process is tedious, and requires great manipulative skill to obtain satisfactory duplicates, and there is no general agreement as to the correct formula to calculate the pentosan present. The chief objection is the wide range of values; thus, we obtained from 3.3 to 5.2 for various roasted nibs, and 7.7 to 10.0 for roasted shell. It will be noted that the highest figure for nib approaches the lowest figure for shell.

One of us found difficulty in getting good duplicates with phloroglucinol, and so we tried the use of Fehling solution to estimate the furfurol, following the process recommended by Eynon and Lane (ANALYst, 1912, 37, 41-44), and using Kröber's table to calculate the pentosans. The results were little better, the disagreement apparently being due to the different amounts of reducing bodies produced. Further, we found that the mere addition of boiling water to aid in grinding the shell, with subsequent evaporation of the water, greatly reduced the percentage of pentosans obtained, one shell giving as low a figure as $4 \cdot 7$.

Jolles (Zeitsch. Analyt. Chem., 1906, 196) prefers to titrate the furfurol, asing bisulphite. 
Jäger and Unger (Ber., 1902, 35, 4440) state that other substances distil over which upset the subsequent precipitation and cause a precipitate which is not the same as when pure furfurol is used. It is only rarely that all the furfurol is distilled over at 400 c.c., 500 to 600 o.c. usually being necessary. They state that a much more uniform precipitation is affected by the use of barbituric acid. (Precipitate $\times 0.4659=$ furfurol.)

Results obtained by Barbituric Acid Method :

Pentosan: Percentage on the Fat-Free Material.

\begin{tabular}{l|c|c}
\hline & Raw Nib. & Raw Shell. \\
\hline $\begin{array}{l}\text { Devin and Strunk (Ulrich, Arch. Pharm., 1911, 249, 549) } \\
\text { Prochnow ("Dissertation Braunschweig," 1908) }\end{array}$ & $\begin{array}{c}1.0 \text { to } 1.6 \\
-\end{array}$ & $\begin{array}{l}3.0 \text { to } 5 \cdot 3 \\
6.3,8.6\end{array}$ \\
\hline
\end{tabular}

Criticisms of the Method.-The refinement suggested by Jäger and Unger does not improve matters appreciably, the figures which we obtained for roasted nib being $2 \cdot 6$ to $4 \cdot 3$, and $8 \cdot 8$ to $9 \cdot 0$ for roasted shell, natural variations which are great enough to render the process of little or no value. Prochnow concludes from his results, noting the great variations between them and those of Dekker and Lührig and Segin, that the pentosan determination is of no great value for the determination of shell in cocoa. Ulrich states that his results and those of other investigators prove that this method for determination of shell in cocoa has no value when the shell content is below 30 per cent.

\section{5. "Cocoa Red" Method.}

Ulrich (ANalyst, 1912, 37, 52) obtained the following percentages of ferric chloride precipitate on the fat-free material : Roasted nib, 10.7 to 16.8 ; raw nib, $12 \cdot 1$ to $17 \cdot 1$; and shell, 0 . Our figures show a wider range for nib, and from 1.3 to $4 \cdot 8$ for shell.

Ferric Chloride Precipitate per Cent. on Fat-Free Material.

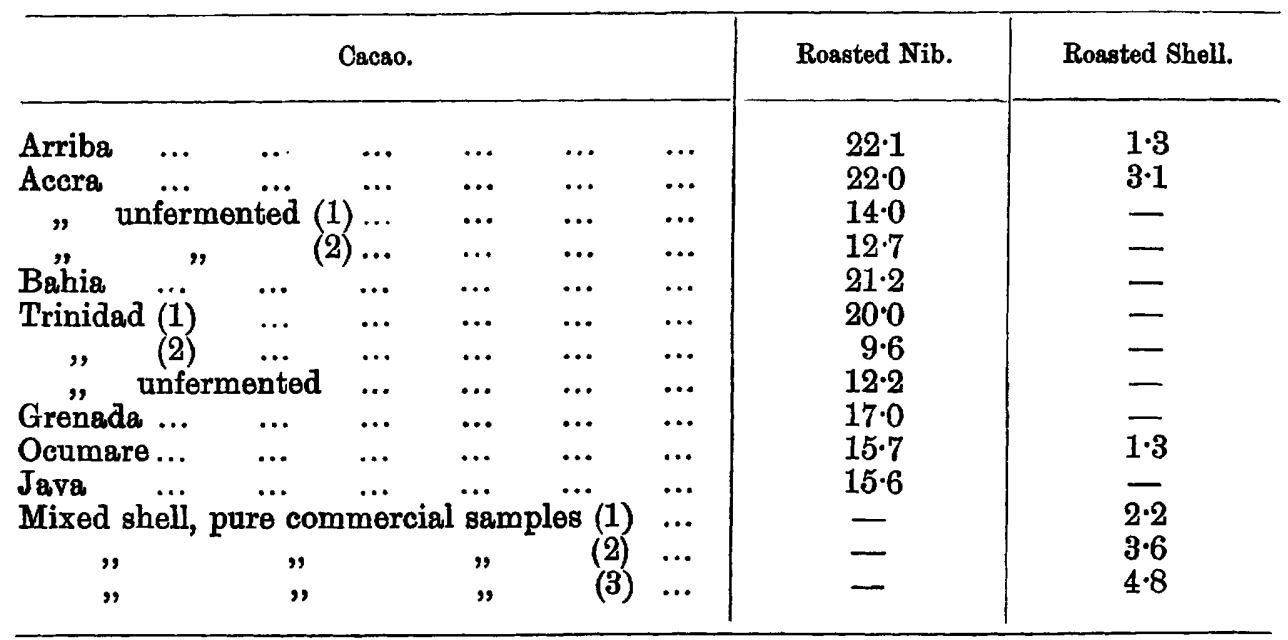


Ulrich only claims for his method that " the presence of 10 per cent. and upwards of shell can generally be ascertained." This modest conclusion is arrived at by the consideration of a mass of figures expressed to four places of decimals. Ulrich is apparently of opinion that only " cocoa red" is estimated. Actually other tannin compounds are precipitated at the same time (note the figures on unfermented nib above). He quite incorrectly assumes that the cocon red is entirely absent from the cacao shell. The oriollo cacao bean is often almost white, and cocoa red is developed during fermentation, and consequently a highly fermented cocoa is richer in cocoa red than one which has been mildly fermented. During the fermentation tannin compounds spread from the beans to the shell. Zipperer (loc. cit.) gives the cacaotannic acid, soluble in 80 per cent. alcohol, in raw shell as varying from 3.80 to 9.15 per cent. Taking these facts into account, we cannot recommend Ulrich's lengthy process; possibly, when we have a more definite knowledge of the tannin compounds present in cacao, a useful method may be devised for the estimation of cocoa in shell powder, but the variation in the figure for nib will always be fatal to its use for the estimation of small quantities of shell in cocoa.

\section{Methods involving Use of the Microscope.}

Before the grinding of cocoa essence became such a fine art, it was possible, by means of the microscope, to identify with certainty the larger particles of shell, and to form an approximate idea as to the quantity of shell present. With the advent of modern machinery, more thorough grinding of the cocon is effected, and the distinction between particles of shell and particles of nib becomes more difficult. Processes have been suggested in which use is made of stains for colouring the particles of shell or nib.

"Ruthenium Red" Method.-We find the following the best method of using this :

Mix the sample with 5 per cent. solution of lead acetate. Add a few drops of ruthenium red dissolved in lead acetate. This stains the mucilage cells a bright pink. About 10 per cent. of an average shell powder becomes stained, but the results are rather irregular, and we find it impossible to distinguish between cocoas containing 15 per cent. and 30 per cent. of shell. This process was the subject of much discussion in the famous legal case in 1910.

H. B. Gerrans, "Detection of Cocoa Husk" (J. Chem. Tech., 1916, p. 17.)-This process depends on the theory that shell absorbs a solution of ferric chloride, whilst cocon does not. Ferrocyanide is finally added, which stains the shell blue. We experimented with this method, and found that many particles of shell showing obvious shell structure do not stain. There is some danger of getting a precipitate of ferric ferrocyanide, which may be taken for shell. We tried removing the fat, but found that fat-free shell did not stain, and that the size of particles makes no difference. The process is valueless, as much as 30 per cent. of shell escaping detection.

The method of Wasicky and Wimmer (AnaLisst, 1916, 41, 46) requires ultraviolet light and a special microscope. It suggested to us the use of the light from a 
mercury lamp. By this light the cacao particles appear bluish-green and the shell greenish-brown. The opacity of the particles interferes, and the method has no quantitative value. Of the various methods we have tried, we prefer that worked out at our suggestion by Mr. Bicklin :

New Method: Phloroglucinol and Iodine Staining.-Phloroglucinol was used as a possible stain for isolating shell tissue. It was found that while this did not give a stain indicating lignified tissue-i.e., "cherry-red "-yet it oleared the shell particles and heightened the colour somewhat. After treatment with phloroglucinol, iodine was added before putting on cover-slip. This stained the starch of the caceo and left the shell untouched. In this way shell particles were clearly isolated.

Details of Process.-Put about $0.25 \mathrm{grm}$. of sample in a very small beaker, and add 2 to 3 c.c. of phloroglucinol (phloroglucinol 1 grm., rectified spirit 20 c.c., distilled water 80 c.c.). Mix thoroughly, and allow to stand for fifteen minutes. Pour off the bulk of the liquid and transfer a small quantity to a slide. Add a spot of pure hydrochloric acid and a spot of $\frac{\mathrm{N}}{10}$ iodine. Mix thoroughly with a glass rod and put on a cover-slip. In this form the preparation will soon dry and be useless for examination. Hence, if it be desirable to keep the slide more than a few hours, the mount should be treated as follows: After adding iodine and stirring, allow the slide to stand to dry, protected from dust. When dry add drop of glycerol, stir well, and place on the cover slip.

We consider this process an improvement on any of the methods we have tried, but it is liable to all the usual errors associated with microscopic methods. Apart from the fact that with finely ground cocoas it is impossible to distinguish with certainty between particles of shell and particles of nib, we have no definite proof that the colouring agents used exercise an absolutely selective action. There is also the great question of sampling and the personal variation which must occur in preparing the microscopic slides. Consequently, the microscopic processes for cocor although they give useful information in experienced hands, cannot be regarded as giving quantitative results. A mixture of 20 cocoas gave on sieving-

$$
\begin{array}{llllll}
0.003 \text { inch }, 0.004 \text { inch } & \ldots & \ldots & \ldots & 74 & \text { per } \\
\text { Less than } 0.003 \text { inch ... } & \ldots & \ldots & \ldots & 6 & \text { ", }
\end{array}
$$

Sieving separates and measures aggregates, not the actual particles. Under the microscope the average size of the cocoa particles was $20 \mu(0.0008$ inch), and of the shell used in our experiments $30 \mu(0.0012$ inch).

\section{Colour of Ethereal Extract.}

O. Keller (Arch. Pharm., 1917, 255, 405) founds his process on his observation that the ethereal extract of pure cacao kernels is colourless or faintly yellow, whilst the extract of husks is distinctly brown. The colours are estimated by comparison with a solution of ferric chloride containing $0.1 \mathrm{grm}$. iron in 100 c.c. The extract from pure powdered bean is matched by 2.4 c.c. and shell by at least 3.5 c.c., the average being $4 \cdot 4$ to $4 \cdot 5$. The author's figures show that the process is useless for estimating shell. We investigated the process, and found that the colour was not 
seriously affected by the wetness of the ether, nor by the treatment of the shell with alkali, nor by contact with iron machinery. But the figure obtained is very appreciably affected by the fineness of the shell; the smaller the particles the greater amount of colour is extracted (for variation in amount of extract with fineness, see under Fibre Estimation). Thus, with West African cacao we obtained the following figures: Raw shell, coarse pieces, 3.0 ; finely ground, 12.0 . Roasted shell, coarse pieces, 6.5 ; finely ground, $10 \cdot 0$. Alkalised shell, coarse pieces, $4 \cdot 0$; roasted shell, finely ground in iron mortar, 14.0.

\section{Ash Content and Alkalinity of the Ash.}

The use of these to estimate shell was proposed by Lührig (Zeitsch. Untersuch. Nahrungs. Genussm. 1903, 12, 161, and ANaLYst, 1905, 30, 206). For a general discussion of the ash of cacao shell, see Baker and Hulton (ANALYst, 1918, 43, 193). The wide variation in the ash content of the shell of various types of cacao, due to treatment on the plantation, has already been dealt with, and the effect of the processes at the factory on the ash content is considerable. We find this figure of practically no value for the estimation of shell, although it gives useful hints on the method of manufacture of the cocoa. In the paper by Baker and Hulton the mean analyses of pure shells were given. It will be of interest to give analyses of actual factory outputs-that is, of the shell which might be used for purposes of adulteration. Below we give analyses of the principal commercial shells, sold on the English market in bulk. These are obtained from mixtures of many varieties of cacao, and give one an accurate idea of the kind of shell actually available in quantity.

Ash of Cacao Shell (1918): Percentage Composition.

\begin{tabular}{|c|c|c|c|c|c|c|c|}
\hline Shell. & $\begin{array}{l}\text { Total } \\
\text { Ash. }\end{array}$ & $\begin{array}{c}\text { Ash Insoluble } \\
\text { in Water. }\end{array}$ & $\begin{array}{l}\text { Ash Soluble } \\
\text { in Water. }\end{array}$ & $\begin{array}{c}\text { Alkalinity } \\
\text { of Water- } \\
\text { Soluble Ash. } \\
\left(\text { as } \mathrm{K}_{2} \mathrm{O}\right) \text {. }\end{array}$ & $\begin{array}{l}\text { Ohlorine (as } \\
\mathrm{NaCl).}\end{array}$ & Fat. & Moisture. \\
\hline 1. & $14 \cdot 42$ & $2 \cdot 89$ & $11 \cdot 63$ & $5 \cdot 69$ & 0.22 & $8 \cdot 8$ & $10 \cdot 5$ \\
\hline 2. & $11 \cdot 60$ & $7 \cdot 77$ & $3 \cdot 83$ & 1.93 & 0.37 & 3.0 & $10 \cdot 0$ \\
\hline 3. & $10 \cdot 14$ & $5 \cdot 70$ & $4 \cdot 44$ & $1 \cdot 66$ & 0.10 & $4 \cdot 2$ & $8 \cdot 2$ \\
\hline 4. & $9 \cdot 96$ & 6.99 & $2 \cdot 97$ & 1.34 & 0.19 & $12 \cdot 7$ & $2 \cdot 7$ \\
\hline 5. & $9 \cdot 69$ & $4 \cdot 67$ & 5.02 & $2 \cdot 55$ & 0.33 & $9 \cdot 0$ & $9 \cdot 1$ \\
\hline 6. & $8 \cdot 87$ & $3 \cdot 33$ & $5 \cdot 54$ & $2 \cdot 12$ & 0.12 & 11.9 & $3 \cdot 0$ \\
\hline 7. & $8 \cdot 74$ & 4.07 & $4 \cdot 67$ & $2 \cdot 28$ & 0.44 & $5 \cdot 8$ & $3 \cdot 8$ \\
\hline 8. & $8 \cdot 34$ & 3.53 & $4 \cdot 81$ & $2 \cdot 23$ & 0.22 & $5 \cdot 2$ & $9 \cdot 0$ \\
\hline 9. & $7 \cdot 83$ & 3.02 & $4 \cdot 81$ & $2 \cdot 34$ & 0.34 & $3 \cdot 6$ & 8.7 \\
\hline 10. & $7 \cdot 80$ & $3 \cdot 58$ & $4 \cdot 22$ & $1 \cdot 91$ & 0.12 & $5 \cdot 0$ & $10 \cdot 6$ \\
\hline 11. & $7 \cdot 78$ & $3 \cdot 29$ & $4 \cdot 49$ & $1 \cdot 72$ & 0.06 & $9 \cdot 3$ & $3 \cdot 2$ \\
\hline 12. & $7 \cdot 69$ & 3.00 & $4 \cdot 69$ & $2 \cdot 19$ & 0.15 & $3 \cdot 9$ & $8 \cdot 1$ \\
\hline 13. & $7 \cdot 32$ & $3 \cdot 07$ & $4 \cdot 25$ & $2 \cdot 02$ & $0 \cdot 29$ & $3 \cdot 0$ & $9 \cdot 0$ \\
\hline Average & $9 \cdot 24$ & $4 \cdot 22$ & 5.01 & $2 \cdot 30$ & 0.22 & $6 \cdot 5$ & $7 \cdot 3$ \\
\hline
\end{tabular}

The alkalinity of the water-soluble ash was determined on the filtrate by titration with standard acid. 


\section{Soluble Silica Processegs.}

This process suggested by Zipperer, Matthes, and Müller (Zeitsch. Untersuch. Nahrungs. Genussm. 1906, 15, 95), has been proved by Matthes and Rohdich (Zeitsch. off. Chem., 1908, 14, 166) to be quite unreliable. They find that from the examination of twenty specimens of caca beans the amount of soluble silica varies from 0.02 to 0.88 per cent.

10. Iodine Value of the Fat (Welman, Zeitsch. öf. Chem., 1901, 7, 500).

It has been suggested that the percentage of shell present in cocoa could be ascertained from the iodine value of the fat. As the range of iodine values for butter from nib overlaps the range for shell butter, this method is obviously useless, and becomes even ridiculous when we remember that nib contains 54 per cent. of butter and shell only 5 per cent.

\section{Cold Water Extraot.}

It seemed probable that the cold water extract of cocoa would be much less than that of cacao shell. Actually they are almost identical if expressed on the fat-free, and this figure is useless for estimation of shell.

\section{Germs.}

Raw cacao beang contain 0.7 per cent. of "germs" (these are the hard rodshaped radicles of the seed). As we have stated, the examples of nib and shell of which we give analyses are germ-free. Germs are usually very completely separated from the nib. In this separation some machines produce a residual containing up to 12 per cent. of germs. Hence, although the quantity of germs in cacao beans is small, shell is sometimes seen on the market containing a fair percentage of germs. The analytical figures for germs are therefore of interest in connection with the estimation of shell. The figures which we have obtained for germs are similar to those published by Richards (Analyst, 1918, 43, 214): Moisture, $5 \cdot 1$ to $5 \cdot 5$; ether extract, $4 \cdot 1$ to $5 \cdot 6$

On fat-free dry material :

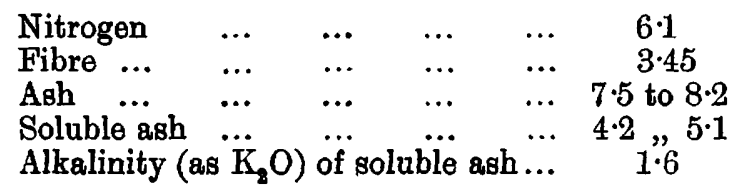

It will be noted that the presence of germs in added shell, if ignored, would cause one to under-estimate the amount of shell from either the nitrogen or fibre figure.

Conclusion.-We have seen that the chief difficulties in the way of an accurate determination of cacao shell are-(1) The natural variation in cacao shell due to botanic variety and to the distinctive treatment which the bean receives in each country; (2) that cacao shell is not a definite chemical substance, and hence the estimation can only be of a purely empirical character.

We have reviewed the various processes for estimating shell, and have conoluded 
that, with all its faults, the only one employed by itself which is capable of giving results of any value is the estimation of the crude fibre. It was reported in the ANALYST $(1918,43,205)$ that the method of estimating shell in cocoa was then receiving official consideration. We hope that the publication of our work may be found of assistance in any research which is being conducted. We find that there is no process which will determine so low a percentage as 5 per cent., but we consider that if the analyst deducts 8 per cent. from the shell percentage, as the mean of a number of analyses he finds by the fibre process, he may safely report that the cocoa contains at least the remainder.

In the Cocoa Powder Order, 1918, the amount of shell in cocoa powder was defined-Grade "A" to contain not more than 2 per cent. of shell, and Grade " B" not more than 5 per cent. of shell. It will be clear from the above that in our opinion no analytical method by itself, or in conjunction with others, will enable the analyst to distinguish between cocoa containing 2 per cent. and cocor containing 5 per cent. of shell.

In conclusion, we should like to thank Mr. B. W. J. Warren, F.I.C., and Miss G. R. Woodhead, B.Sc., for their assistance.

Messrs. Cadbury's laboratories, Bournevillie.

Mgasgrs. Rowntrea's Laboratories, York.

\section{Discussion.}

Mr. P. A. Ellis Rrchards considered the authors were in rather a pessimistic vein in that they condemned all the recognised processes for the analysis of cocoa without suggesting an improved method. However, he quite agreed with them in the statement that when cocoa nib and shell were extremely finely ground the levigation process was of very little use. He himself preferred to base his conclusions as to the composition of a sample on a general consideration of all the analytical figures taken in conjunction with a full microscopical examination.

Mr. CRIBB said that he found himself in entire agreement with the main conclusion to which the authors of the paper had arrived-viz., that of all the methods suggested for the determination of the proportion of shell, the estimation of the fibre gave the nearest approximation to the truth; but at the same time he never thought it safe to express an opinion on one factor alone, and preferred to base his conclusions on as many other determinations as possible. Microscopic examination should, of course, never be omitted, as by it alone could the actual presence of shell be established.

In former days, when cocoa was less finely ground and also more uniform as regards the fineness of grinding, he had found that counting the particles of mucilage under the microscope, after staining with ruthenium red, afforded valuable quantitative indications, especially in the case of small proportions of shell. He found that, counting horizontally and vertieally (near to the diameters) of a uniformly distributed and thin preparation under a $\frac{7}{8}$ inch cover-glass, that the number of particles in the case of shell was from 90 to 120 , while in the case of good nib it rarely exceeded 4, and was often between 0 and 2. Of course, great care had to be taken to get the 
preparations of uniform thickness. Now that the majority of cocoas are ground so much more finely, the method had lost much of its value, except that it gave a sure indication of the absence of shell when such was the case.

In view of the difficulty of obtaining ruthenium red, he had recently been employing methylene blue instead. It stained the mucilage well, but if the solution was too strong the starch and other structural elements were also coloured.

Where larger proportions of shell were present he had hoped that the estimation of the cocoa red would prove useful, as that substance was supposed to be entirely absent from the shell, but unfortunately his experience again coincided with that of the authors, as he also had obtained figures as high as 4.5 per cent. in the shell alone.

He inquired whether the authora had any knowledge as to the mucilage content of the shell of unripe as distinguished from ripe beans.

In reply, Mr. Knapp said: The various figures are all expressed on the dry fatfree material unless otherwise stated. The figures given on the cacao beans represent extremes that would be unlikely to occur with a manufactured cocos, since this is always made from a mixture of beans. We agree with Mr. Cribb that the microscopic examination has a qualitative value, but we do not think that the average microscopist can obtein quantitative results. With regard to the ruthenium red test, this atains the mucilage, which occurs not in but on the seed-coat. I do not know if it is greater in amount on " unripe " beans, but would not be surprised to find it absent altogether from washed beans. The suggestion of sieving would be of use in certain cases if applied with discretion, but it was always possible that the shell might be finer than the cocoa or the cocoa finer than the shell, although we believe that if they were ground together the shell usually came out coarser than the cocoa.

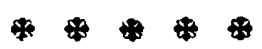

